\title{
Motivational Techniques Employed by Teachers' in Secondary School Teaching and Learning of Account
}

\author{
Dr. Egboka, Patience Ndidi \\ Department of Educational Management and Policy \\ Faculty of Education \\ Nnamdi Azikiwe University, Awka.
}

\begin{abstract}
The purpose of the study was to ascertain the motivational techniques employed by teachers in secondary schools for teaching and learning of account in Awka education zone of Anambra State. It was a descriptive research guided by two research questions and two null hypotheses. The public and private secondary schools in the area were studied. All the 99 teachers of account in the area formed the population. There was no sampling. A researcher-developed questionnaire was the instrument for data collection. Four experts, all in Nnamdi Azikiwe University validated the instrument. The reliability of the study was established through pilot test in Onitsha education zone of Anambra State. The reliability coefficient of section 1 is 0.87 and that of section 2 is 0.84 respectively. The direct approach was employed in the data collection. Out of the 99 copies of the instrument distributed, 96 copies were retrieved and correctly filled. They were subjected to data analysis. Mean and standard deviation were used to answer the research questions while the null hypotheses were tested at 0.05 level of significance using t-test. Findings of the study indicated that teachers in secondary school employed both positive negative reinforcement techniques for teaching and learning of account. Based on this, it was recommended that teachers should also motivate their students through appreciation when they perform well (for instance, a teacher can say, 'high five' to a wellbehaved student). Such verbal and facial expressions can enhance meaningful learning in the classroom. It was also recommended that teachers can employ negative reinforcement (such as sending a problematic student out of class) to motivate their students but the teacher should aim at using it to make problematic student become a better student.
\end{abstract}

Keywords:- Motivational techniques, teachers', secondary school, teaching and learning of Account.

\section{INTRODUCTION}

Generally, education is the means through which knowledge and skills are acquired for the development of any nation. The acquisition of these knowledge and skills take place mainly in the classroom. The classroom is an important place in the operation of any school which holds the students together and offers them the opportunity of achieving the purpose of education. The classroom determines what the child eventually becomes morally and academically. This goes to prove how indispensable the provision of adequate, conducive, suitable and childfriendly classroom is for school children to achieve their goals. This implies that the classroom occupies a very important place in any system of education. The classroom is the teacher's theatre of operation; a place that makes or mars his career; a place where he is happy to be if he teaches with confidence. That is why the place of the teacher in teaching and learning process is a crucial one and should not be played with. One of the subjects the teachers teach in the classroom is account.

Account is a school subject that helps the learners to understand the process of providing financial information about the financial transactions carried out by a business organization so that decisions about the financial activities of the business could be ascertained by users (Umar, 2017). It involves the maintenance of an organization's financial records of revenue and expenditure, as well as accounting for the flow of funds into and out of an organization. Account is an academic course that equips students with relevant skills and knowledge needed for occupation in accounting field. Jat and Jugu (2008) defined account as a service activity which provides social communication through which changes and improvements in business activities are communicated to various users in order to allow them make informed decision. Akinbuli (2006) stressed that account is a branch of accounting that enables business managers to report their stewardship, keep records of all financial transactions, provides records for tax assessment, planning and decision making.

The objectives of account as a school subject, according to Osuala in Umar (2017) are to: give students additional vocational skills that will enhance their opportunities for future occupational success, to enable students become proficient in financial transactions and management, equip students with better understanding of business practices and procedures, to provide vocational training to students in the practical knowledge of daily bookkeeping activities, and to help students understand the cycles and steps involved in financial accounting so that the relations of each step to all other steps are properly understood. By these objectives, it is expected that students of financial accounting on graduation from tertiary institutions should be able to secure paid job or be selfemployed. Account, as a school subject requires calculations and as such, many students do not offer the course. They therefore need motivation to be interested in the subject. 
Edikpa, (2007) noted that behaviours are regulated by motivation. Luke, (2012) asserts that motivation is the process that arouses, energizes, directs, and sustains behaviours and performance. That is, it is the process of stimulating people to action to achieve a desired task. Motivation can also be conceived of as whatever it takes to encourage workers to perform by fulfilling or appealing to their needs. It is goal directed, and therefore cannot be outside the goal of any organization. Latham (2012) also states that motivation is the process that initiates and maintains goal-directed performance. Another word to explain motivation is reinforcement. Motivational techniques come in form of reinforcement.

The term reinforcement means to strengthen, and is used in psychology to refer to anything which strengthens or increases the probability of a specific response. Reinforcement is another way the teacher can promote teaching and learning in the classroom and preventing misbehaviour. A class that is less chaotic is most likely to achieve the set goals. Omenyi 2007 stressed on the importance of reinforcement. She suggests that the use of rewards, praise on a behaviour that is expected to repeat again promotes that behaviour.

According to Abbas, and Khurshid, (2013) and Jones and Jones (2001) there are four types of reinforcement: positive, negative, punishment and extinction. Each of them could be used to motivate students.

Positive reinforcement: This means adding something in order to increase a response. The most common type of positive reinforcement is praise and reward. This can be best illustrated when a teacher praises or rewards student/students for work well done and when he/she behaves well in the class.

Negative reinforcement: This means taking something negative away in order to increase a response. This can be applied when a teacher complains about the students' poor behaviour or performance in class and refuses to praise or give - rewards to those affected. The elimination of this negative behaviour or stimulus is reinforcing and will likely increase the chances that he will not behave that way again. Negative reinforcement is employed when students misbehave in classroom. Negative reinforcement employed by account teacher in secondary school classroom includes penalty, blame, wrong, snub, sending the problematic students out of class and poor grading to the misbehaved student (Ofoegbu, 2014).

> Punishment: Punishment refers to adding something over since in order to decrease behaviour. The most common example of this is disciplining (e.g cutting of the grass) a child for misbehaving. The teacher does this so that the child begins to associate being punished with the negative behaviour. The students will not like the punishment and therefore will stop behaving in the manner.
Extinction: This happens when a teacher removes something in order to decrease behaviour. Reward or punishment is to be given where necessary in oidcr to motivate and to cope with discipline situations in the class and the school. Researchers have shown that positive reinforcement is the most powerful of any of these. Adding a positive reinforcement to increase a response not only works better, but allows both teacher and student(s) to focus on the positive aspects of the situation.

Influencing factor in the motivational techniques employed at secondary school teaching and learning account could be type of institutions where the account teacher teaches. Abbas and Khurshid (2013) revealed that teachers' in the government school employed positive motivational techniques for their students' in teaching and learning process, whereas teachers belongs to private school employed negative motivational techniques for young learners teaching and learning process. It was not certain whether motivational techniques are employed in the area of the study. In the light of this, the main purpose of this study was to ascertain motivational techniques employed by teachers in secondary school teaching and learning of account in Awka education zone of Anambra State. Specifically, the study sought to determine as follows:

- Positive reinforcement technique for teaching and learning of account in Awka education zone of Anambra State.

- Negative reinforcement technique for teaching and learning of account in Awka education zone of Anambra State.

\section{* Research Questions}

The following research question guided the study

$>$ What positive reinforcement techniques are employed by secondary school teachers for teaching and learning of account in Awka education zone of Anambra State?

$>$ What negative reinforcement techniques are employed by secondary school teachers for teaching and learning of account in Awka education zone of Anambra State?

\section{* Hypotheses}

The following null hypotheses were tested at 0.05 level of significance:

$>$ Teachers of account in public and private secondary schools will not differ significantly in their mean ratings on positive reinforcement technique employed for teaching and learning of account.

$>$ Teachers of account in public and private secondary schools will not differ significantly in their mean ratings on negative reinforcement technique employed for teaching and learning of account. 


\section{METHOD}

The study was conducted in the Awka education zone. The Awka education zone is one of the six education zones in Anambra State, Nigeria. The public and private secondary schools in the area were studied. It was a descriptive survey research. All the 99 teachers of account in the area formed the population. This comprised 81 account teachers in government and 18 account teachers in private secondary schools respectively. There was no sampling. A researcher-developed questionnaire was the instrument for data collection. Four experts, all in Nnamdi Azikiwe University validated the instrument. Two, out of the four experts were chosen from Educational
Management and Policy Department while the other two were chosen from Measurement and Evaluation unit of the Department of Educational Foundations. The suggestions of the experts guided the construction of the final instrument which was subjected to reliability test. This was done through pilot test in Onitsha education zone of Anambra State. The reliability coefficient of section 1 is 0.87 and that of section 2 is 0.84 respectively. The direct approach was employed in the data collection. Out of the 99 copies of the instrument distributed, 96 copies were retrieved and correctly filled. They were subjected to data analysis. Mean and standard deviation were used to answer the research questions while the null hypotheses were tested at 0.05 level of significance using t-test.

\section{RESULTS}

Research Question 1: What positive reinforcement techniques are employed by secondary school teachers for teaching and learning of account in Awka education zone of Anambra State?

\begin{tabular}{|c|c|c|c|c|}
\hline $\mathbf{S} / \mathbf{N}$ & $\begin{array}{l}\text { Positive reinforcement employed for } \\
\text { teaching and learning account: }\end{array}$ & $\overline{\bar{X}}$ & SD & Remarks \\
\hline 1. & Praising verbally when students does well & 3.89 & .99 & Strongly Agree \\
\hline 2. & Grading (chance to get good marks) & 3.53 & .93 & Strongly Agree \\
\hline 3. & Appreciation(high fives) & 3.56 & .92 & Strongly Agree \\
\hline 4. & Facial expression & 3.52 & .83 & Strongly Agree \\
\hline 5. & Gestures & 3.64 & .86 & Strongly Agree \\
\hline 6. & Clapping/thumbs up) & 3.65 & .96 & Strongly Agree \\
\hline 7. & Admires when the students behave well & 3.55 & .86 & Strongly Agree \\
\hline \multirow[t]{2}{*}{8.} & Compensates the students with (pencils) & 3.75 & .84 & Strongly Agree \\
\hline & Calling parents with positive feedback & 3.54 & .88 & Strongly Agree \\
\hline
\end{tabular}

Table 1:- Data Analysis on Positive Reinforcement Technique for Teaching and Learning of Account (N=96)

Data in Table 1 show that teachers' in secondary school employed positive reinforcement technique for teaching and learning of account. The item by item analysis shows that all the items achieved mean scores ranging from 3.54 to 3.89 which indicated strongly agreement that they employed these positive reinforcement techniques. It is observed that the standard deviation showed homogeneity in responses of the respondents which fall between the range of .83 to .99 .

Research Question 2: What negative reinforcement techniques are employed by secondary school teachers for teaching and learning of account in Awka education zone of Anambra State?

\begin{tabular}{|c|c|c|c|}
\hline $\begin{array}{l}\mathrm{S} / \mathrm{N} \\
\begin{array}{l}\text { Positive reinforcement employed for } \\
\text { teaching and learning account: }\end{array}\end{array}$ & $\overline{\bar{X}}$ & SD & Remarks \\
\hline $\begin{array}{l}\text { 1. Penalty } \\
\text { 2. Blame } \\
\text { 3. Wrong } \\
\text { 4. Snub } \\
\text { 5. Send the problematic students out of class } \\
\text { poor grading }\end{array}$ & $\begin{array}{l}3.89 \\
3.53 \\
3.56 \\
3.52 \\
3.64 \\
3.65\end{array}$ & $\begin{array}{l}.99 \\
.93 \\
.92 \\
.83 \\
.86 \\
.96\end{array}$ & $\begin{array}{l}\text { Strongly Agree } \\
\text { Strongly Agree } \\
\text { Strongly Agree } \\
\text { Strongly Agree } \\
\text { Strongly Agree } \\
\text { Strongly Agree }\end{array}$ \\
\hline
\end{tabular}

Table 2:- Data Analysis on Negative Reinforcement Technique for Teaching and Learning of Account $(\mathrm{N}=96)$

Data in Table 2 show that teachers' in secondary school employed negative reinforcement technique for teaching and learning of account. The item by item analysis shows that all the items achieved mean scores which ranged between 3.52 and 3.89 and were all rated strongly agree. It is observed that the standard deviation showed homogeneity in responses of the respondents which fall between the range of .83 to .99 . 
Testing of null Hypotheses

Null Hypothesis 1: Teachers of account in public and private secondary schools will not differ significantly in their mean ratings on positive reinforcement technique employed for teaching and learning of account.

\begin{tabular}{|lccccccc|}
\hline Type of Institution & $\mathbf{N}$ & $\bar{X}$ & SD & $\boldsymbol{\alpha}$ & Df & t-val & p-val Remark \\
\hline Public Owned & 20 & 3.50 & 1.14 & & & & \\
& & & 0.05 & 0.86 & 87 & 0.27 & Not Significant \\
Private Owned & 69 & 3.51 & 1.13 & & & & \\
\hline
\end{tabular}

Table 3:- t-test analysis of positive reinforcement techniques employed for teaching and learning of account $\mathrm{N}=89$ Source: Field Study, 2018.

Data in Table 3 indicate that the p-value is not significant at alpha level of 0.05 . Since the p-value is greater than the alpha value (0.05), the null hypothesis is not rejected. This means that the mean responses of account teachers in government owned secondary school do not significantly differ from their counterpart in private secondary school on the extent they employed positive reinforcement technique for teaching and learning of account in Awka education zone of Anambra State.

Hypothesis 2: Teachers of account in public and private secondary schools will not differ significantly in their mean ratings on negative reinforcement technique employed for teaching and learning of account.

\begin{tabular}{|lccccccc|}
\hline Type of Institutions & $\mathbf{N}$ & $\bar{X}$ & SD & $\boldsymbol{\alpha}$ & Df & t-val & p-val Remark \\
\hline Public Owned & 20 & 3.46 & 1.13 & \multirow{2}{*}{0} & \multirow{2}{*}{87} & \multirow{2}{*}{0.18} & Not Significant \\
& 69 & 3.43 & 1.16 & & & & \\
Private Owned & 69.62 & &
\end{tabular}

Table 4:- t-test analysis of negative reinforcement techniques employed for teaching and learning of account Source: Field Study, 2018.

Data in Table 4 indicate that the t-value of 0.18 is greater than the alpha value $(0.05)$, at the alpha level of 0.62 and 87 degree of freedom. The null hypothesis is therefore accepted. This means that the mean responses of account teachers in government owned secondary school do not significantly differ from their counterpart in private secondary school on the negative reinforcement techniques employed for teaching and learning of account in Awka education zone of Anambra State.

\section{$>$ Discussion of Results}

The analysis for the first research question presented all the items as the positive reinforcement technique employed by teachers for teaching and learning of account and were rated strongly agree with mean scores ranging from 3.54 to 3.89. This implies that positive reinforcement technique is employed by teachers for teaching and learning of account in secondary school in Awka education zone of Anambra State. This is in line with Bernier, Simpson and Rose (2012). Who noted that positive reinforcement employed by account teacher in secondary school classroom include group activities high fives, praising verbally, smiling at the students, clapping/thumbs up, calling parents with positive feedback, stickers, pencils, grading, homework passes or extra homework points and appreciating a good studying student.

The result in Table 3 revealed that account teachers in government owned secondary school do not significantly differ from their counterpart in private secondary school on the extent they employed positive reinforcement technique for teaching and learning of account. This means that type of institution where account teachers teaches does not affect the extent they employed positive reinforcement technique for teaching and learning of account in Awka education zone of Anambra State.

In the same manner, the analysis of research question 2 presented all the items as the negative reinforcement technique employed by teachers for teaching and learning of account and were rated strongly agree with mean scores ranging from 3.52 to 3.89 . This implies that negative reinforcement technique is also employed by teachers for teaching and learning of account in secondary school in Awka education zone of Anambra State. This is in line with Ofoegbu (2014) who identified some negative reinforcement employed by account teacher in secondary school classroom to include penalty, blame, wrong, snub, sending the problematic students out of class and poor grading to the misbehaved student.

The result in Table 4 revealed that account teachers in government owned secondary school do not significantly differ from their counterpart in private secondary school on the extent they employed negative reinforcement technique for teaching and learning of account. This is in support by Tahir, Khurshed, Ishfaq and Gul (2015) that negative reinforcement strengthen students' behavior to escape from an unpleasant situation or a way of preventing something unpleasant from occurring. This means that type of 
institution where account teachers teaches does not affect the extent they employed negative reinforcement technique for teaching and learning of account in Awka education zone of Anambra State.

\section{CONCLUSION}

The conclusion of the researcher in this study is the teachers of account in secondary schools in Anambra state employed both positive and negative reinforcement to motivate their students in the teaching and learning of account.

\section{RECOMMENDATIONS}

The following recommendations are made for teachers of account but can be employed by other teachers:

$>$ Teachers are praise their students verbally when students do well. The students can also be given chance to get good grades in the class works.

$>$ Teachers should also motivate their students through appreciation when they perform well (for instance, a teacher can say, 'high five' to a well-behaved student). Such verbal and facial expressions can enhance meaningful learning in the classroom.

Teachers are to use gestures, for instance, clapping/thumbs up or gifts (for instance, compensating the students with pencils or biros) to motivate them to learn.

> Calling parents with positive feedback is another positive reinforcement teachers should employ to motivate their students.

$>$ Teachers can employ negative reinforcement (such as sending a problematic student out of class) to motivate their students but the teacher should aim at using it to make problematic student become a better student.

\section{REFERENCES}

[1]. Abbas, M. \& Khurshid, F. (2013). Motivational techniques and learners academic achievement at primary level Islamabad Model colleges. Global Journal of Human Social Science Linguistics \& Education, 13(3), 1-11.

[2]. Akinbuli, S. F. (2006). Financial accounting principles and application. Lagos: B Print Publishers.

[3]. Bernier, S., Simpson, C. G. \& Rose, C. A. (2012). Positive and negative reinforcement in increasing compliance and decreasing problematic behavior. National Teacher Education Journal. 45-51.

[4]. Edikpa, E. C (2007). Strategies for enhancing staff development and motivation in Anambra state secondary schools. Unizik Orient journal of Education, 3 (1), 99-105.

[5]. Hukamdad, M. (2014). Effectiveness of reward and punishment as modfiers of students. Kent Publish Company, Boston, Massachusetts.

[6]. Musaazi, J. C. S. (2016). The theory and practice of educational administration (1st Ed.), London and Oxford: Macmillan Education Ltd.
[7]. Ofoegbu, F. I. (2014). Teacher motivation as an essential factor for classroom effectiveness and school improvement. College Student Journal, Department of Educational Administration and Foundations, University of Benin, Benin City, Nigeria, 3(1), 54-69.

[8]. Jat, R. B \&Jugu, Y. G (2008). Modern financial accounting: Theory and practice, Jos: Ehindero (Nig) Limited

[9]. Jones, V.F. \& Jones, L.S. (2001) Comprehensive classroom management: creating communities of support and solving problems ( $6^{\text {th }}$ ed.) Boston: Allyn \& Bacon.

[10]. Latham, G. (2012). Work motivation theory and research at the dawn of the twenty first century. Annual Review of Psychology, 56, 485-516

[11]. Luke, F. (2012). Organization Behaviour ( $8^{\text {th }}$ ed.). Boston: Irwin McGraw Hill.

[12]. Omenyi, A. S. (2007). Leadership and school management: A problem-based approach. J. Goshen Publishers, Awka

[13]. Tahir, T., Khurshed, T., Ishfaq, U. \& Gul, M. (2015). Effective motivation techniques used by teachers in academic achievements at secondary school level in Folk Grammer School No 1 from District Haripur. The Shield, 10(1), 75-86. (ISSN-1991-8410).

[14]. Umar, R.T. (2017). Comparative study of direct and cooperative method of teaching financial accounting in federal colleges of education, north, east, geoOpolitical zone, Nigeria. KIU Journal of Social Science. 3(1), 257-262 